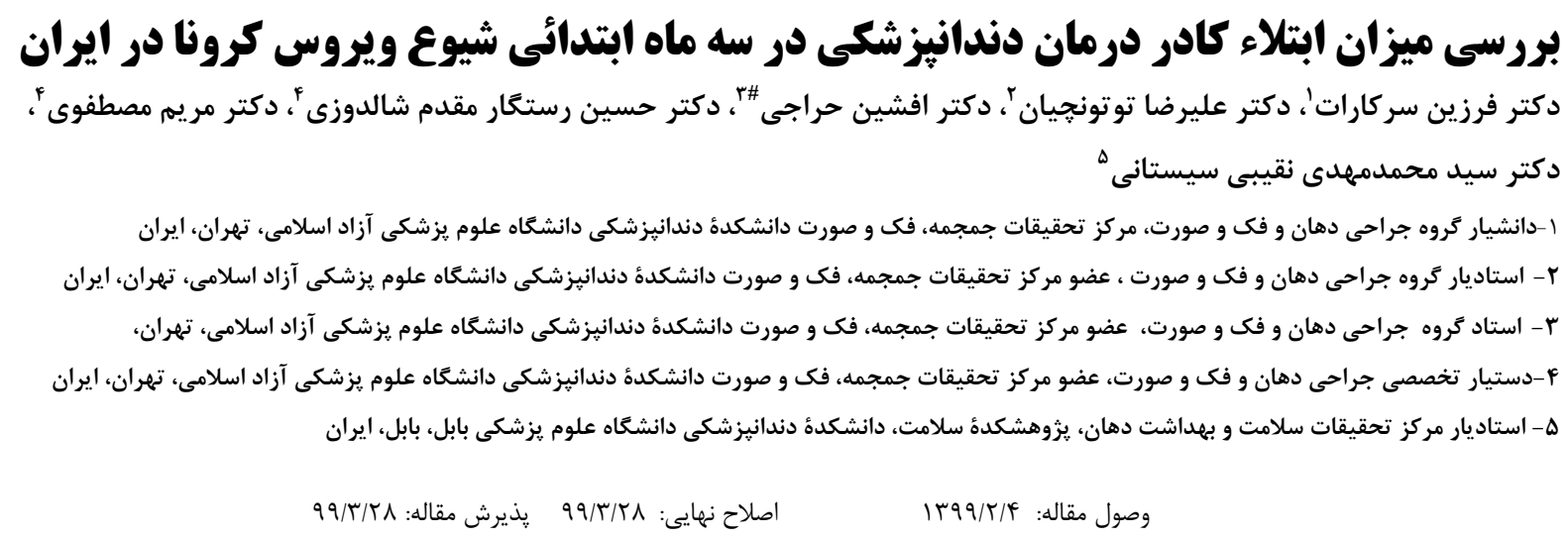

\title{
Evaluation of dentistry staff involvement with COVID-19 in the first 3 month of epidemiologic spreading in Iran
}

Farzin Sarkarat ${ }^{1}$,Alireza Tootoonchian ${ }^{2}$, Afshin Haraji ${ }^{3}$, Hossein Rastegarmoghaddam Shaldoozi ${ }^{4}$, Maryam Mostafavi $^{4}$, Seyyed Mohammad Mehdi Naghibi Sistani ${ }^{5}$

\footnotetext{
${ }^{1}$ Associated Professor,Oral and maxillofacial surgery Dept, Craniomaxillofacial Research Center, Faculty of Dentistry, Tehran Medical Sciences, Islamic Azad University, Tehran, Iran.

${ }^{2}$ Assistant Professor,Oral and Maxillofacial Surgery Dept; Member of Craniomaxillofacial Research Center, Faculty of Dentistry, Tehran Medical Sciences, Islamic Azad Universit,

${ }^{3}$ Professor,Oral and Maxillofacial Surgery Dept; Member of Craniomaxillofacial Research Center, Faculty of Dentistry, Tehran Medical Sciences, Islamic Azad Universit

${ }^{4}$ Post Graduate Student, Oral and Maxillofacial Surgery Dept; Member of Craniomaxillofacial Research Center, Faculty of Dentistry, Tehran Medical Sciences, Islamic Azad Universit

${ }^{5}$ Assistant professor, community Dentistry and Oral Health Dept, Faculty of Dentistry, Bobol University of Medical Science, Babol, Iran.
}

\section{Abstract}

Received: May 2020 ; Accepted: June 2020

Background and Aim:The new coronavirus - 2 is known to be a major threat to public health around the world. Common ways of transmitting the virus include direct transmission (sneezing, coughing and inhaling infected droplets and aerosols) and contact transmission (oral mucosa, nose and conjunctiva). When dental services are provided, large amounts of aerosols are produced during working with equipment. Iran was one of the main centers for the spread of the disease at the beginning of the epidemic, so this study evaluates the extent and severity of COVID-19 in the pre- and post-quarantine period.

Material and Methods: The study was conducted through an online questionnaire, in which 1,100 member of dental association volunteered to participate in the study.

Results: Since past 3 months, 74 (28.1\%) reported Covid-19 symptoms, while totally, 18(2.2\%) had definite infection. Ceramists had the highest incidence (50\%) and dental students had the lowest incidence $(19.3 \%)$ of symptoms. Among dental treatment staff, definitive rate of COVID-19 was higher in ceramists and dental students compare to dentists and dental specialists. In this study, $11.8 \%$ of the participants knew one of the members of the medical staff who died of COVID-19. The mean age of definite patients was $35.24 \pm 12.24$ yarrs old.

Conclusions: The low rate of definitive infection of dental treatment staff in this study shows that disinfection of the environment and sterilization and use of protective devices can normally be effective and useful in preventing the spread of disease and infection.

Key words: COVID-19, Virus diseases, Dental Staff, Corona virus

*Corresponding Author: afshin_haraji@yahoo.com

J Res Dent Sci. 2020; 17 (2) : 137-145 
سابقه و هدف: ويروس

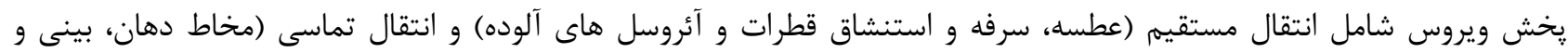

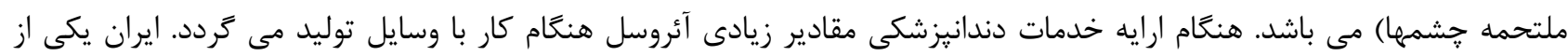

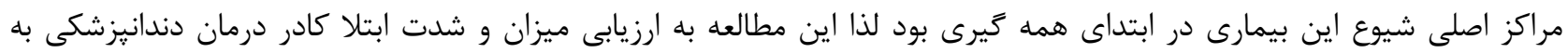
COVID-19

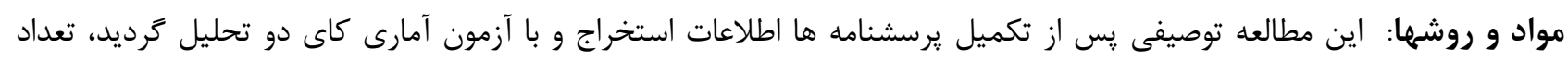

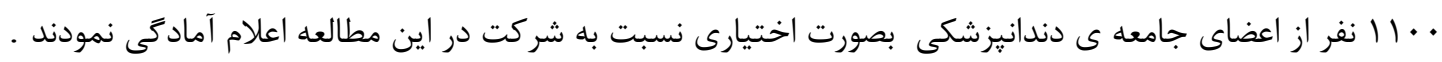

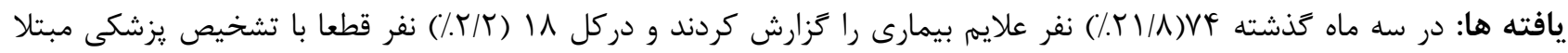

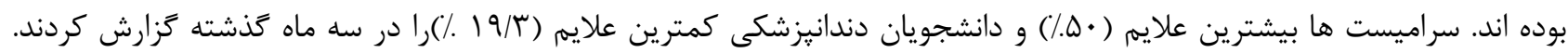

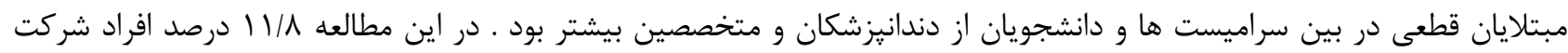

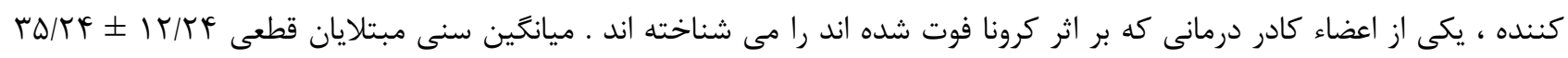

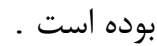
نتيجه كيرى: ميزان پايين ابتلاء قطعى كادر درمان دندانيزشكى در اين مطالعه نشان مى دهد كه ضد عفونى محيط و استريليزاسيون

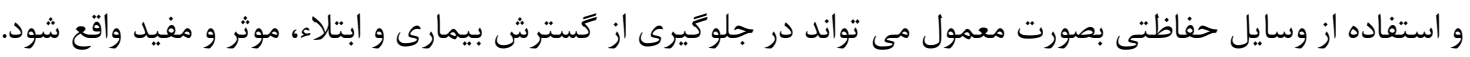

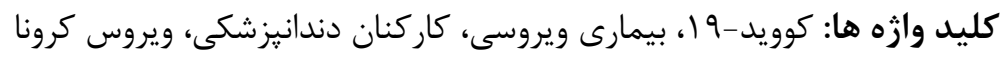

(به طور متوسط fl (ب) روز) از زمان آغاز بيمارى اتفاق مقدمه: مى افتد. (9) (1) راه هاى معمول پخش ويروس شامل انتقال مستقيم (بواسطه

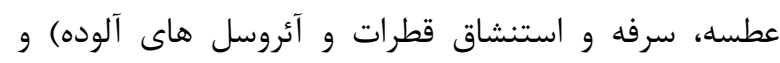
انتقال تماسى (تماس با مخاط دهان، بينى و ملتحمه

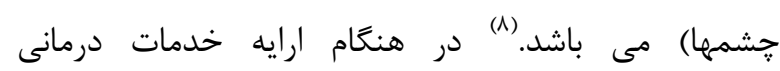

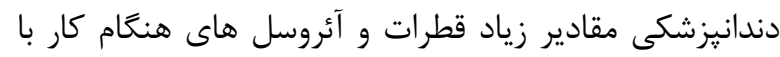
وسايل مانند هندييس هاى با سرعت بالا يا ساير وسايل اولتراسونيك توليد مى گردد. بنابراين در طول مدت مات درمان بيمار به دليل ارتباط مستقيم و نزديك دندانيزشك و بيمار،

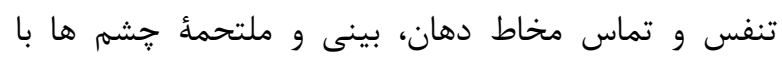

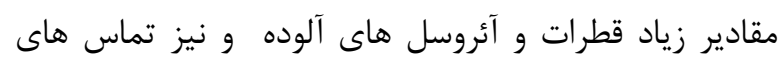
SARS-nCoV-2 مكرر با بزاق و خون، احتمال انتقال

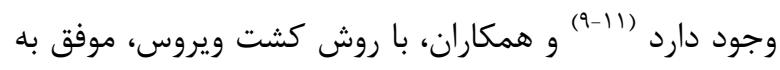

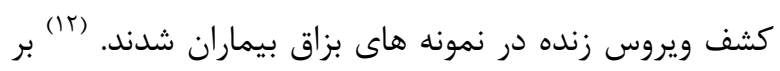
اساس كزارش موردى انجام شده در آلمان نشان داده شده بـ بـان

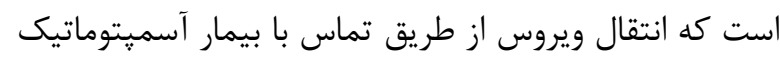
ويروس كروناى جديد - T مولد نشانكان حاد و شديد تنفسى SARS-nCoV-2) مى شود، مولد بيمارى كرونا ويروس (COVID-19)بوده و به عنوان يك تهديد كنندهٔ بزرگ سلامت همعانى در جهان

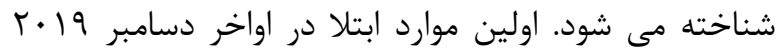

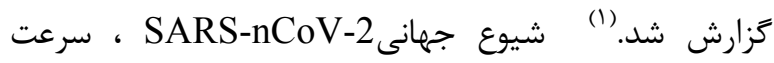
بالاى گسترش و انتقال بيمارى و ميزان مرى و مير قابل

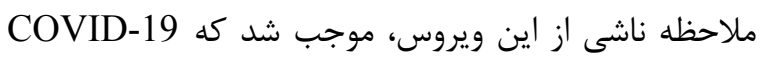
به عنوان يك إيدمى و اورزانس جهانى از سوى سازئ مانس

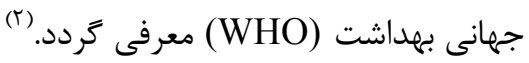
علائم و نشانه هاى COVID-19 يس از دوره نهفتتىى 1 تا

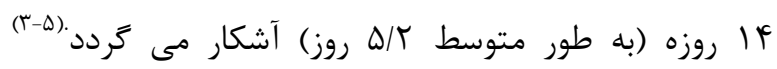

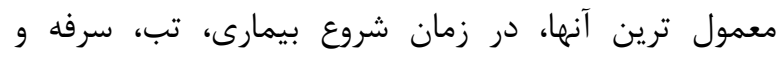

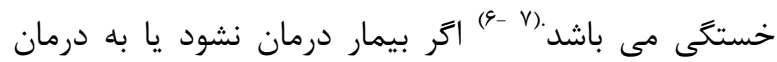

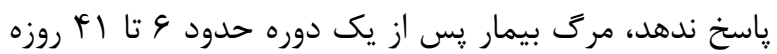


قرارگرفتن در معرض بيمارى (Disease Exposure Index) ينج بخش دندانيزشكى، خدمات بيمارستانى، داميزشكى، دئ، يزشكى عمومى و :برستارى در منزل در صدر قرار گرفتند كه برخلاف دندانيزشكان و داميزشكان، سه مورد ديخر مستقيما در حال مراقبت و ارايه خدمت به بيماران مبتلا به دمانه

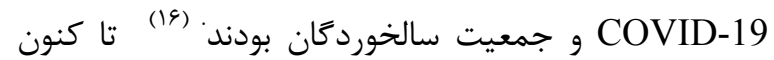
هيج مطالعه اى كه به صورت اختصاصى به بررسى ميزان خطر ابتلا به COVID-19 در ميان گروه هاى مختلف كاركنان خدمات درمانى دندانيزشكى ( Dental healthcare (providers بيردازد، انجام نشده است. با توجه به اينكه در ابتداء كسترش جهانى اين بيمارى، ايران يكى از مراكز اصلى شيوع اين بيمارى بوده و هم اكنون نيز جزء كشورهاى دركير با مقادير ابتلاء بالاى اين بيمارى مى باشد، اين مطالعه به

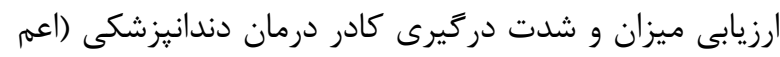
از : دانشجويان دندانيزشكى، دندانيزشكان عمومى، متخصصين دندانيزشكى، دستياران كنار دندانيزشك و ونير سراميست ها) با COVID-19 و نيز ارزيابى وجود يا عدم وجود ارتباط با ميزان كار كادر درمانى در دوره قبل و بعد از

$$
\text { قرنطينه مى يردازد. }
$$

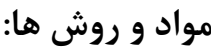

مطالعه به روش توصيفى و با استفاده از برسشنامه آنلاين

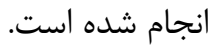
با توجه به فعاليت مراكز درمانى دندانيزشكى و دانشكده هاى دندانيزشكى در ابتداء ايام همه كيرى بيمارى و در معرض قرار كرفتن كادر درمان دندانيزشكى (دندانيزشكان عمومى ، متخصصين دندانيزشكى ، دانشجويان دندانيزشكى ، دستياران كنار دندانيزشك و سراميست ها) با بيماران، ميزان ابتلا به ويروس مولد COVID-19 قبل و بعد از انجام درمان و ايزولاسيون بايد اندازه گيرى مى شد . بنابراين تصميم گرفته

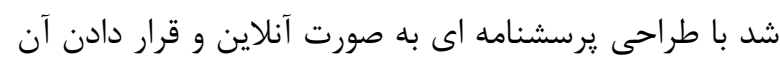
در اختيار كادر درمان دندانيزشكى از شرايط و وضعيت ابتلاء

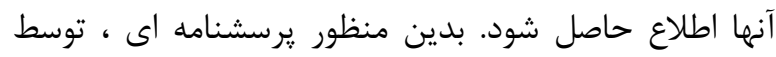

نيز امكانيذير است. (ז)" اهميت اين مسأله زمانى بارزتر است كه بيماران در دوره نهفتتى بيمارى يا زمانى كه از بيمار بودن خود آكاهى ندارند، براى دريافت درمان دندانيزشكى

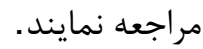
تا به امروز مطالعات متعددى ييرامون ارتباط مشاغل مختلف همانف

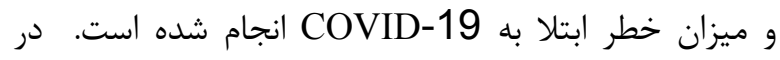
اكثر اين مطالعات مشاغل مربوط به سيستم هاى خدمات درمانى، يرمخاطره ترين مشاغل از اين منظر قلمداد شده اند

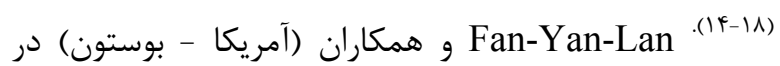
إيريل •r.r.r، مطالعه اي با هدف مشخص كردن مشاغل ير خطر از جهت انتقال محلى در زمان شيوع اوليه COVID-19 در جند كشور انجام دادند. براى انجام اين مطالعه موارد قطعى COVID-19 از كزارش هاى دولتى كشور هاى هنَ كنَ، زُاين، سنَايور، تايوان، تايلند و ويتنام

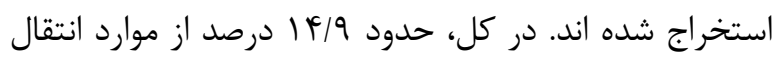
محلى موارد احتمالى انتقال شغلى بودند. در ميان موارد احتمالى انتقال شغلى به ترتيب :كاركنان خدمات سلامت، راننده ها و كاركنان وسايل نقليه، كاركنان خدمات فروش،

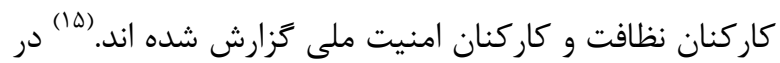
آغاز شيوع ويروس در سطح جهانى ، ايران در بين كشورهايى قرار كرفت كه بيشترين مبتلايان را دارا بود، به طورى كه طبق آمار هاى رسمى وزارت بهداشت، درمان و آموزش

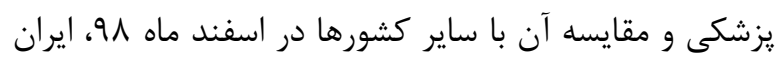

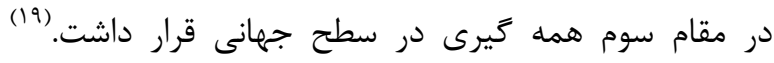
Barbieri

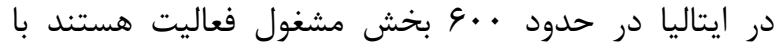
تمركز بر جنبه هايى كه كارمندان را در خطر ابتلا در طى إييدمى COVID-19 ، بر اساس ميزان قرار ترفتن كارمندان در معرض بيماريها، نزديكى فيزيكى بين افراد ضمن فعاليت و امكان كاركردن از راه دور طبقه بندى كردند. و جنين نتيجه كرفتند كه بخش هايى كه بيشترين ميزان خطر در معرض

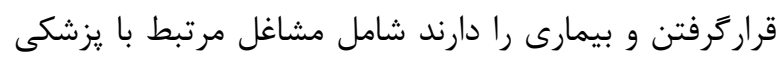
و خدمات سلامت هستند. در اين ميان از لحاظ شاخص درس مرسط 


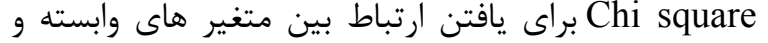
مستقل مورد تجزيه و تحليل قرار گرفتند P value . كمتر از ه • • به صورت يك نتيجه قابل توجه و مورد قبول آمارى در نظر گرفته شدند. از آزمون ANOVA براى بررسى بين جند گروه مختلف با همين معيارها استفاده گرديد. لينك يرسشنامه از ع ارديبهشت ماه و9٪| بمدت دوهفته در اختيار كادر درمان دندانيزشكى قرار گرفت ، در اين تاريخ ميزان كل مبتلايان به بيمارى COVID-19 در ايران طبق آمار رسمى، براساس معيارهاى قطعى تشخيصى، ع إM إيمار

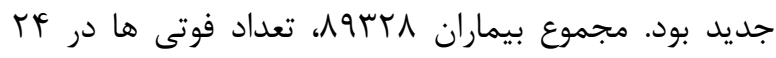
ساعت منتهى به تاريخ فعال شدن يرسشنامه V9 نفر و

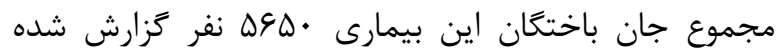
بود. از ميان كل بيماران سو 19 19 نفر، بهبود يافته و ترخيص شده بودند. و و9 • ن نفر از بيماران قطعى در وضعيت شديد و تحت مراقبت قرار داشتند.(9)در تاريخ غير فعال شدن

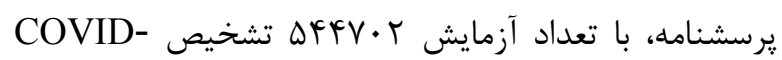
19، طبق آمار رسمى، براساس معيارهاى قطعى تشخيصى

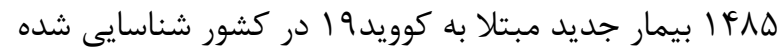
بود. مجموع بيماران COVID-19 در كشور هזוس•1 نفربود. تعداد فوتى ها در F ساعت منتهى به زمان غيرفعال شدن يرسشنامه \&1 نفر و مجموع جان باختخان اين بيمارى

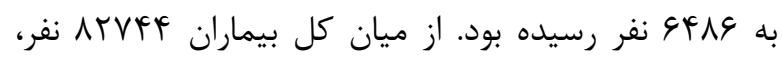
بهبود يافته و ترخيص شده بودندو از تعداد TVYA نفر در وضعيت شديد اين بيمارى تحت مراقبت قرار داشتند. (19)

يافته ها

اطلاعات يافته ها به صورت درصد اعلام و يس از جمع آورى جهت بررسى ارتباط با متغيرها از آزمون كاى دو استفاده شد. بعد از مطالعات آمارى و تحليل داده ها مشخص كرديد كه سن شركت كنندگان در اين آزمون بين \| تا VD سال بوده

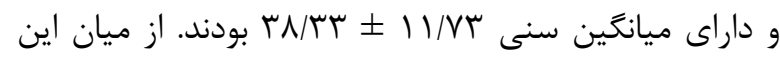

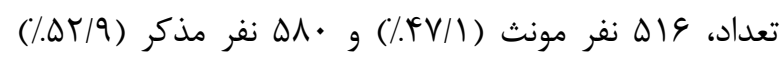

أعضاء تيم تحقيقاتى حاضر كه همكى عضو بخش جراحى دهان،فى و صورت و مركز تحقيقات جمجمه، فك و صورت دانشكده دندانيزشكى آزاد اسلامى تهران هستند، طراحى

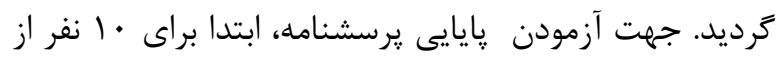
واجدين شرايط شركت، متن يرسشنامه ارسال گرديد و ״اسخها جمع آورى شدند. سيس بعد از گذشت يكهفته مجدداً افراد مذكور، مورد آزمون گرسشنامه قرار گرفتند كه تفاوت معنى دارى بين دو آزمون وجود نداشت. همجنين جهت تاييد روايى بر اساس روش دلفى كه در اصل به منظور

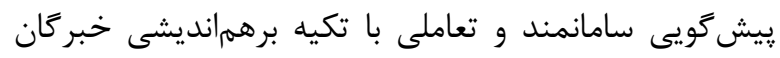
ابداع شده و در آيندهيزوهى استفاده مىشود عمل گَرديد. در اين فرايند، ساختارى براى جمعآورى و طبقهبندى دانش موجود در نزد كروهى از كارشناسان و خبر گان كه سه نفر از اساتيد بخش جراحى دهان و فك و صورت دانشكده ميباشند بنا گرديد كه از طريق توزيع يرسشنامههايى در بين اين افراد و بازخورد كنترل شده ياسخها و نظرات دريافتى صورت مى گيرد، استفاده گرديد. افراد واجد شرايط حضور در مطالعه كليه كادر درمان دندانيزشكى شامل دندانيزشكان عمومى ، دندانيزشكان متخصص شامل تمام 11 گ دانشجويان دندانيزشكى ، دستياران كنار دندانيزشك و سراميست ها مى باشد. قبل از فعال شدن لينك الكترونيكى بصورت عمومى، آن جهت تست و ارزيابى اوليه براى تعدادى

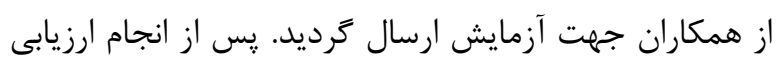
ها در نهايت به جمع بندى نهايى رسيده و فرم نهايى به صورت آنلاين در اختيار كادر درمان دندانيزشكى قرار داده شده است .

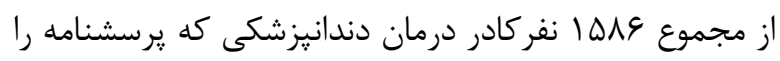
مشاهده كرده اند، بر اساس داده هاى رسيده از سامانه اينترنتى، كل افراديكه بصورت اختيارى و آكاهانه نسبت به

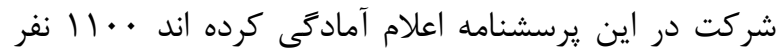

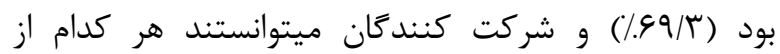
سوالهايى را كه تمايل ندارند، يُاسخ ندهند. داده ها با استفاده از آمار توصيفى و با استفاده از نرم افزار SPSS نسخه الب و 
در ميان شركت كنندكان، //1/ \% از افراد، به وجود يك نفر كادر درمانى دندانيزشكى فوت شده در اثر ابتلاء به COVID-19

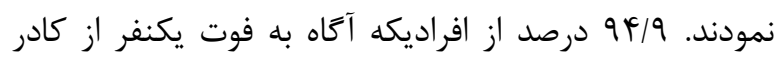

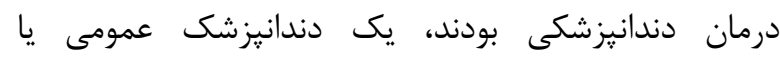
متخصص را ميشناختند كه در اثر بيمارى كرونا فوت شده است. از اين ميان بيش از ץ/ץ^ ٪ نسبت به متخصص(ين)

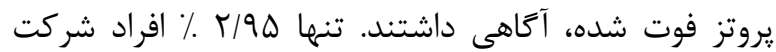
كننده، بيش از يك نفر را در گروه درمانى دندانيزشكى ميشناختند كه بدليل انجام درمان دندان يزشكى براى

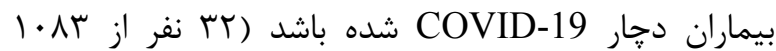

در بررسى مقايسه اى با آزمون x2 Test بين افراديكه علائم وجود بيمارى را در سه ماه كذشته داشتند، نشان داده شد كه به إنه ميزان بروز علائم با ميزان كاركرد كادر درمانى در اسفندماه از داز

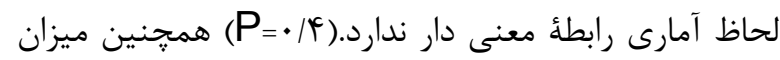

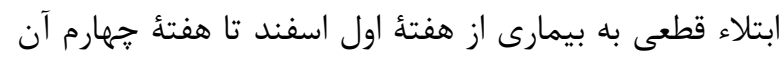

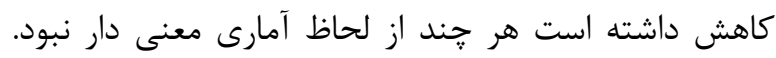
(P= به طور مشابه بررسى ها نشان داد كه ميزان بروز علائم و نشانه ها با كار در ارديبهشت ماه ارتباطى ندارد و

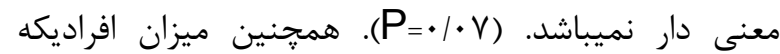
علائم بيمارى را در سه ماه كذشته نشان دادند، در ميان سراميست هاى شركت كننده بيشتر از بقيئ موارد بود ( •ه./)

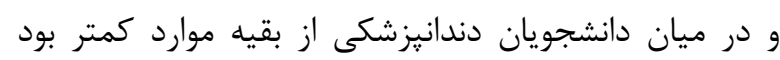

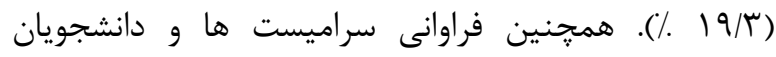
دندانيزشكى قطعا مبتلاء به بيمارى از دندانيزشكان و متخصصين رشته هاى مختلف بيشتر بوده و كمترين فراوانى به دستياران كنار دندانيزشك اختصاص داشت. آقايان ينج درصد علائم تنفسى در سه ماه كذشته رابيشتر از خانم ها

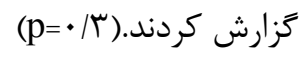

از بين رشته هاى تخصصى دندانيزشكى جراحان دهان و فك

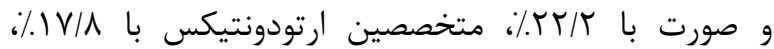
متخصصين يروتزهاى دندانى و : يريودونتيكس هر كدام با 1/1/1\% بيشترين افراد شركت كننده و راديولوزيست هاى

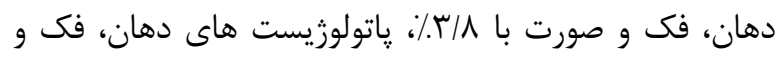

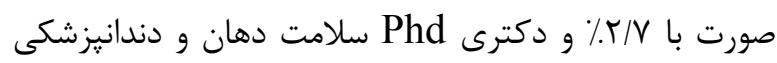
اجتماعى با // ٪ كمترين شركت كنندكان در اين مطالعه را تشكيل دادند. از ميان V^•1 إسخ دهنده به يرسش فعاليت

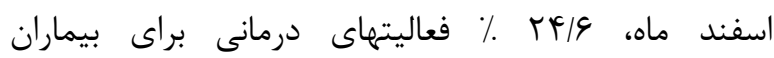
دندانيزشكى نداشته اند و ميزان فعاليت شغلى به ترتيب از

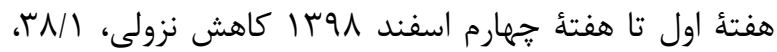
IV/ ، I/ / I/9 درصدى را نشان ميدهد. همجنين از ميان

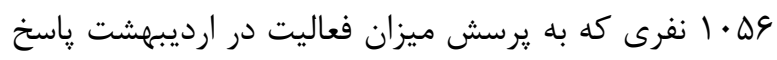

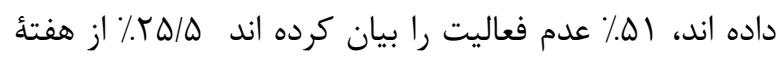
اول ارديبهشت 99 9 افعاليت شغلى را از سركرفته اند.

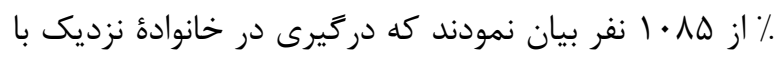
بيمارى كرونا وجود نداشته است. و از ميان وسب نفرى كه عنوان كردند داراى بيمار مبتلاء به كرونا در خانواده بوده اند،

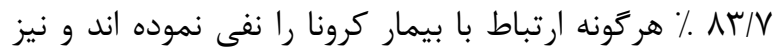
VN/T از VN اين موارد نيز علائم و نشانه هايى از وجود بيمارى

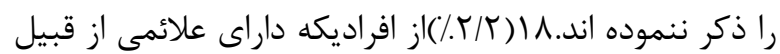
سرفه خشك، تنكى نفس، كَفتكى بينى خشك و موارد

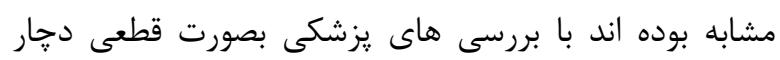

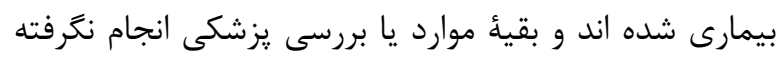

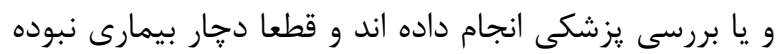

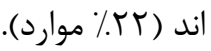
جدول ا- توزيع فراوانى افراد شركت كننده در مطالعه به تفكيك تروه شغلى

\begin{tabular}{|c|c|c|}
\hline تعداد & تعداد(درصد) & كزينه \\
\hline$\Delta \Lambda \Lambda$ & $\% . \Delta F$ & دندان يزشك عمومى \\
\hline $1 M 1$ & $\% \vee v, r$ & متخصص دندن يزشكى \\
\hline$\Lambda r$ & $\% \mathrm{Y}, \mathrm{\varphi}$ & دستياركناردندان يزشك \\
\hline IVA & $\% 19,4$ & دانشجوى دندانيزشكى \\
\hline Q1 & $\%, v$ & سراميست \\
\hline 1.11 & $\% \cdots$ & لـمع \\
\hline
\end{tabular}


جدول r- توزيع فراوانى افراد مورد مطالعه بر اساس وضعيت ابتلا به COVID -19 به تفكيك سن و جنس

\begin{tabular}{|c|c|c|c|}
\hline ميانَين سنى (سال) & تعداد (درصد) & تعداد (درصد) & \\
\hline$r \Delta / T Y$ & $(/ T / M) / T$ & $(\% 1 / 1)^{9}$ & COVID-19 بتلاء قطعى به \\
\hline$r q / 4 q$ & $(1 . \mid N / V 4) 1.4$ & $(/ .19 / r \cdot) \wedge r$ & COVID-19 عدم ابتلاء به \\
\hline KN/Q9 & $(/ . V 9 / 11) \& F$ & $(\% \wedge r / \Delta \cdot) \& 1 \Delta$ & عدم بررسى و يِيخيرى بيشتر \\
\hline r $/ \mathrm{N}$ & $(\%) \cdot \cdots) \Delta \varphi \Delta$ & $(/ . \cdot \cdot) \Delta \cdot r$ & كل \\
\hline
\end{tabular}

اى عنوان نمودند كه تعداد موارد COVID-19 ثبت شده در مانيل - فيلييين به صورت پِيوسته رو به افزايش بوده است و كادر درمان كه در خط مقدم مواجهه با بيماران بوده اند با ريسك بالا آلوده شده بودند. طبق اين مطالعه تعداد ميانكَين

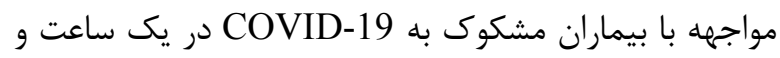

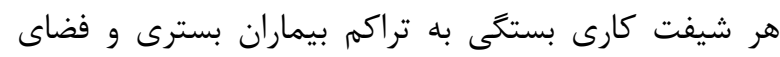

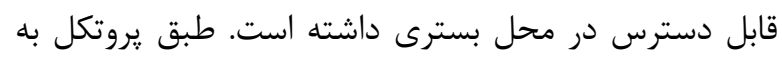

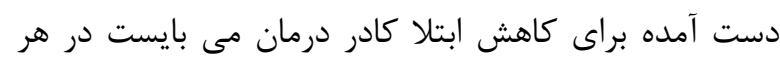
ساعت در هر شيفت كارى حداكثر سه بيمار ويزيت شود و

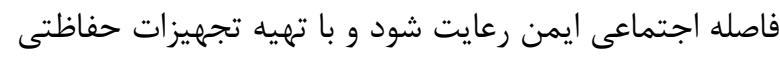
مناسب براى كادر درمان در طول شيفت هاى كارى به

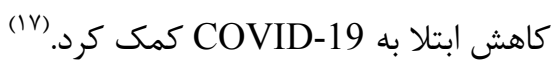
با توجه به بازه سنى، تجمع آمارى در اين مطالعه در بين افراديكه در دهأ سوم تا پِنجم زندكى هستند ديده ميشود كه ميتواند نشاندهنده ميزان علاقةٔ بيشتر به مشاركت در بحث

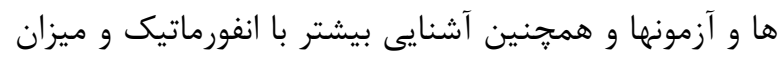

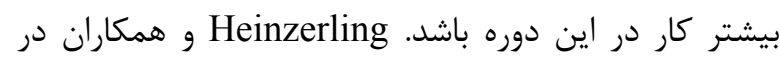

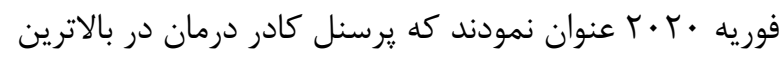

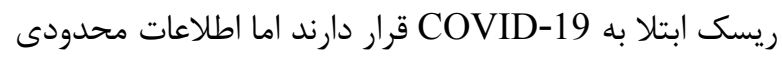
در مورد خَّونكَى انتقال را بيان داشتند. در اين مطالعه عامل اصلى ابتلاء معاينات فيزيكى و تزريق و تجويز دارو عنوان شده بود.(·) در مورد رشته هاى تخصصى شركت كت كننده اكثريت با مواردى است كه كار بالينى و تماس نزديك با بيمار

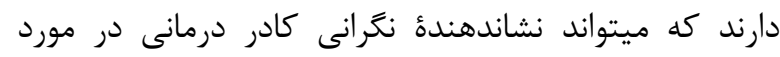
ابتلاء خود و يا بيماران و انتقال COVID-19 باشد. همانطور

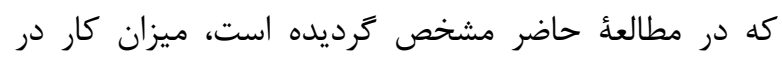

ولى در موارد ابتلاء قطعى اختلاف معنى دارى از لحاظ

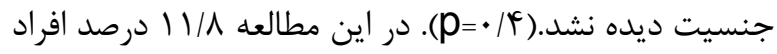
شركت كننده (Y^/انفر)، يكى از اعضاء كادر درمانى كه بر اثر كرونا فوت شده اند را ميشناخته اند كه كوع نفر از آنان به يك متخصص دندانيزشكى، •D نفر به دندانيزشك عمومى و مابقى به دانشجوى دندانيزشكى و سراميست ها اشاره نموده

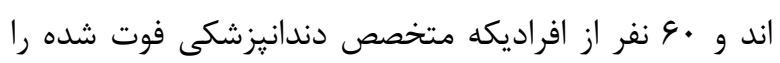
ميشناختند به وجود يك متخصص يروتزهاى دندانى فوت

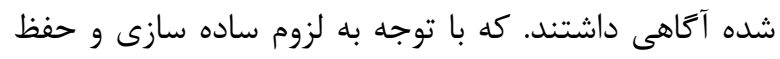

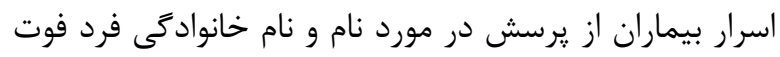
شده، خوددارى گرديد. همجنين تنها T/9 (T نفر) درصد افراد، به وجود بيش از يك نفر فوت شده در كادر درمان دندانيزشكى آكاهى داشتند كه 11 نفر آنها به دندانيزشك

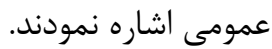
ميانگين سنى افراديكه ق قطعا مبتلا شده بودند

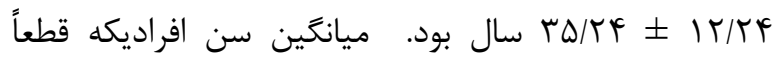

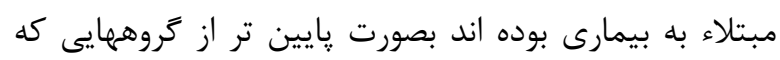

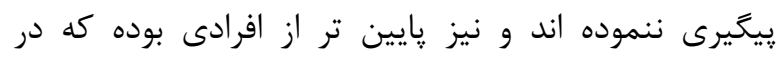
بررسى هاى يزشكى ابتلاء آنها به بيمارى رد شده لرد است،

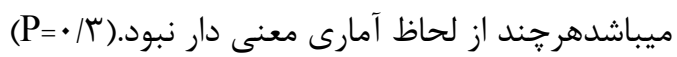

بحث: با توجه به نتايج حاصله و تحليل داده ها مشخص ميشود كه

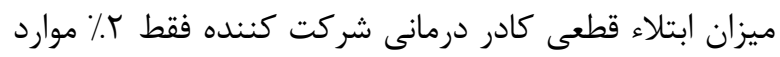
بوده است، درصورتيكه ه V\٪ موارد در اسفند ماه داراى فعاليت شغلى بوده اند. Dy L F و همكاران در •T.T در مطالعه 
ارديبهشت 9ףץ آغاز به كار كرده اند، ابتلاء به بيمارى را

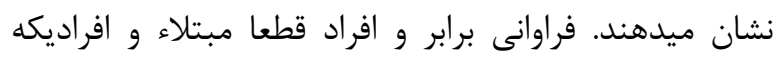
قطعا مبتلا نشده اند در سراميست ها بيشتر از ساير گروهها ميباشد. گَروهماى درمانى در مطبهاى دندانيزشكى امكانات بيشترى براى ضدعفونى كردن و مراقبت از خود انجام ميدهند و بايد در يروتكلهاى مراقبتى در لابراتوار ها بدليل يخش ذرات و هندلينَ قالبهاى بيمار بازنكرى شود. همجنين ميزان ابتلاء قطعى كادر درمان، ارتباط معنى دار با رشته و ميزان تحصيلات داشته است ولى با رشتأ تخصصى لئى افراد ارتباط معنا دارى ندارد. اين مسأله ميتواند نشاندهندة نقش آموزشهاى بهداشتى فردى و اطلاعات بيشتر افراد شاغل در حيطه تخصصى باشد. همجنين كمترين ميزان ابتلاء

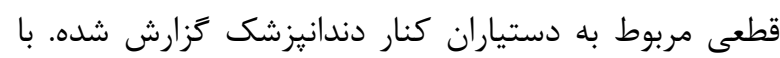

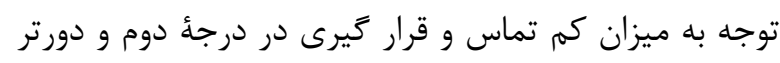

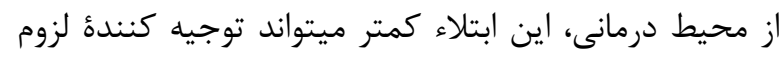
حفظ فاصله و كافى بودن مراقبتهاى معمول رايج در سيستم

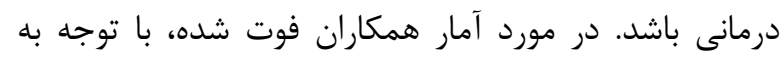
خبر رسانى رسانه ها، افراد شناخته شده بين شركت كنندگًان مشترك خواهد بود و اين به معنى وجود تعداد بالاى فوت شدكان در اثر كرونا ويروس در كادر دندانيزشكى نميباشد. همجنين تمام افراد شركت كننده در مطالعه نيز حتى در صورت درگيرى با بيمارى، بهبودى يافته اند.

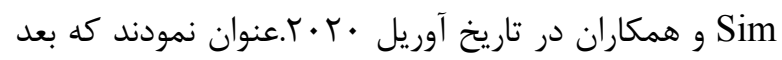

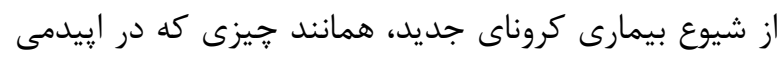
هاى SARS و MERS شاهد بوديم، كاركنان خدمات سلامت (HCW) از نظر خطر انتقال بيمارى و مركى در خط مقدم هستند. جداى از خطرات انتقال مستقيم عفونت بواسطه تماس نزديك با بيماران، كاركنان خدمات سلامت تحت فشار فزاينده استرس هاى روحى و ذهنى نيز قرار كرفته اند كه اين مسأله به نوبه خود باعث اعمال فشار و استرس كارى بيشتر براى ايشان و نيز تضعيف سطح خدماتى

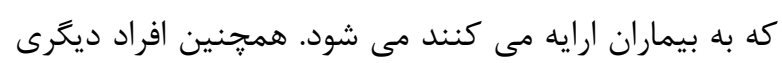
به علت تماس نزديك با افراد در سطح اجتماع ضمن فعاليت
اسفند ماه با كذشت هفته اول به جهارم، كاهش نشان ميدهد كه اين امر ميتواند ثانويه به اخبار دريافتى از رسانه هاى مختلف و موج اول شيوع بيمارى به همراه ترس از ابتلاء و

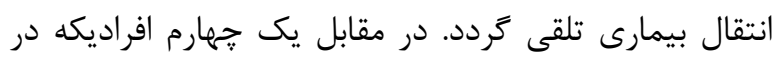

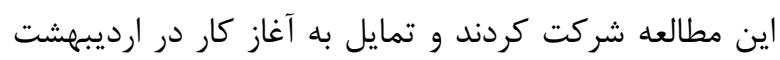

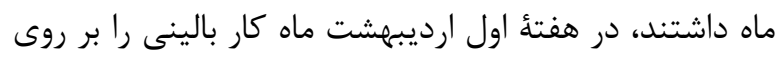

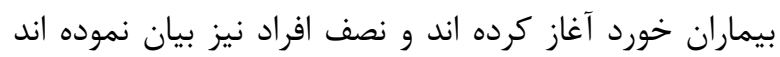
كه در ارديبهشت ماه 99 ا فعاليت شغلى نداشته اند. با توجه به اينكه اكثريت افراد شركت كننده در مطالعه وجود

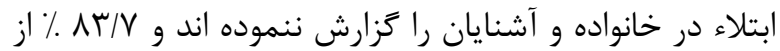
افراديكه داراى ابتلاء در خانواده بوده اند، هرگونه تماس با فرد بيمار را نفى نموده اند، ميتوان وجود علائم و نشانه ها و نيز ابتلاء قطعى به بيمارى را مربوط به انجام فعاليت و كار

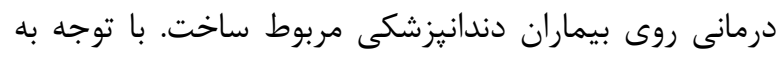
ميزان ابتلاء قطعى r درصد افراد شركت كنيده دمان ميتوان دركيرى كادر دندانيزشكى با بيمارى كرونا را ناجيز دانست البته اين به معنى نفى خطر بيمارى نميباشد بلكه يكى از تئوريهاى موجود موثر بودن اقدامات ضد عفونى و حفاظت فردى روتين كادر دندانيزشكى در درمان بيماران است. همجنين V9 درصد افراديكه داراى علائم و نشانه هاى بيمارى بوده اند، يُيگيرى يزشكى جهت وجود يا نفى ابتلاء انجام نداده اند، پس ميتوان اينكَونه نتيجه گيرى كرد كه

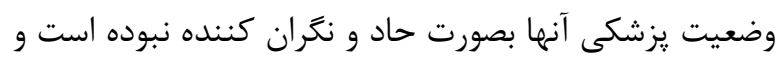

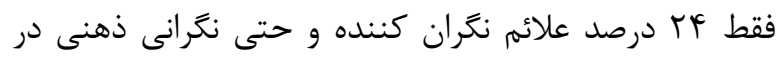
مورد ابتلاء به COVID-19 وجود داشته كه از لحاظ درصد لحد ابتلاء كادر دندانيزشكى معنى دار نميباشد. عليرغم عدم رابطه معنى دار بين ميزان ابتلاء قطعى به بيمارى و هفتأهاى كارى اسفند، شايد انجام يروسه هاى حفاظت بيشتر و يا در نظر كرفتن تمهيدات خاص توانسته باشد از انتقال بيمارى به كادر درمان جلوكيرى نمايد. دورهٔ ايزولاسيون يكماه كامل فروردين براى كادر درمان دندانيزشكى نيز فرصتى بوده كه

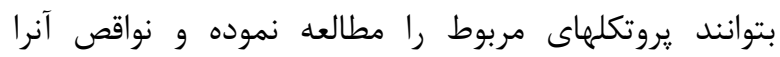
تكميل نمايند و در نتيجه درصد كمى از افراديكه در

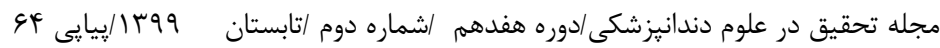




\section{References:}

1-Rothan HA, Byrareddy SN. The epidemiology and pathogenesis of coronavirus disease (COVID19) outbreak. Journal of autoimmunity. $2020 \mathrm{Feb}$ 26:102433.

2-Mahase E. China coronavirus: WHO declares international emergency as death toll exceeds 200 . Bmj. 2020 Jan 31; 368:m408.

3-Li Q, Guan X, Wu P, Wang X, Zhou L, Tong Y, Ren R, Leung KS, Lau EH, Wong JY, Xing X. Early transmission dynamics in Wuhan, China, of novel coronavirus-infected pneumonia. New England Journal of Medicine. 2020 Jan 29.

4-Huang C, Wang Y, Li X, Ren L, Zhao J, Hu Y, Zhang L, Fan G, Xu J, Gu X, Cheng Z. Clinical features of patients infected with 2019 novel coronavirus in Wuhan, China. The Lancet. 2020 Feb 15; 395(10223):497-506.

5-Backer JA, Klinkenberg D, Wallinga J. Incubation period of 2019 novel coronavirus (2019-nCoV) infections among travellers from Wuhan, China, 20-28 January 2020. Eurosurveillance. 2020 Feb 6; 25(5):2000062.

6-Wang W, Tang J, Wei F. Updated understanding of the outbreak of 2019 novel coronavirus (2019-nCoV) in Wuhan, China. Journal of medical virology. 2020 Apr; 92(4):4417. -Ren LL, Wang YM, Wu ZQ, Xiang ZC, Guo L, Xu T, Jiang YZ, Xiong Y, Li YJ, Li XW, Li H. Identification of a novel coronavirus causing severe pneumonia in human: a descriptive study. Chinese medical journal. 2020 Feb 11.

8-Lu CW, Liu XF, Jia ZF. 2019-nCoV transmission through the ocular surface must not be ignored. Lancet (London, England). $2020 \mathrm{Feb}$ 22; 395(10224):e39.

9-Peng X, Xu X, Li Y, Cheng L, Zhou X, Ren B. Transmission routes of 2019-nCoV and controls in dental practice. International Journal of Oral Science. 2020 Mar 3;12(1):1-6.

10-Meng L, Hua F, Bian Z. Coronavirus disease 2019 (COVID-19): emerging and future challenges for dental and oral medicine. Journal of Dental Research. 2020 Mar 12:0022034520914246.

11-Guo H, Zhou Y, Liu X, Tan J. The impact of the COVID-19 epidemic on the utilization of emergency dental services. Journal of Dental Sciences. 2020 Mar 16.

12-To KK, Tsang OT, Yip CC, Chan KH, Wu TC, Chan JM, Leung WS, Chik TS, Choi CY, Kandamby DH, Lung DC. Consistent detection of 2019 novel coronavirus in saliva. Clinical Infectious Diseases. 2020 Feb 12.
حرفه أى خود در خطر أفزايش يافته براى COVID-19 مى باشند. مسافران و كاركنان يرواز ها و كشتى ها، كاركنان سرويس هاى خدمات اورزانس و امنيت مانند يليس ها و آتش نشانان، يرستاران سالخوردگان و كودكان، رانندگان تاكسى ها و ساير وسايل نقليه عمومى عده قليلى از اين دسته (if)

$$
\begin{aligned}
& \text { نتيجه كيرى } \\
& \text { همانطور كه ميدانيم در ابتداى ورود رسمى كرونا ويروس به } \\
& \text { ايران يروتكلهاى حفاظتى و مراقبتى بصورت رايج و معمول در } \\
& \text { حال اجرا بوده و همكاران گروه دندانيزشك يروتكلهاى ويزه و } \\
& \text { اختصاصى و نيز تجهيزات ويزه حفاظتى و مواد ضدعفونى } \\
& \text { كننده مراقبت را در دسترس نداشته و اجرا نميكرده اند. با } \\
& \text { توجه به ميزان پايين ابتلاء قطعى كادر درمان دندانيزشكى در } \\
& \text { مطالعه حاضر اين تئورى ميتواند بدين صورت تأييد شود كه } \\
& \text { انجام مراحل ضد عفونى محيط و استريليزاسيون و همجنين } \\
& \text { استفاده از وسايل شخصى از قبيل ماسك هاى جراحى، } \\
& \text { عينك و دستكش بصورت معمول ميتواند در جلوگيرى از } \\
& \text { گَسترش بيمارى و ابتلاء موثر و مفيد واقع شود. مطالعات و } \\
& \text { بررسى هاى تخصصى بيشترى در اين زمينه لازم بوده و } \\
& \text { توصيه مى شود. }
\end{aligned}
$$


13-Rothe C, Schunk M, Sothmann P, Bretzel G, Froeschl G, Wallrauch C, Zimmer T, Thiel V, Janke C, Guggemos W, Seilmaier M. Transmission of 2019-nCoV infection from an asymptomatic contact in Germany. New England Journal of Medicine. 2020 Mar 5; 382(10):970-1. 14-Sim, Malcolm R. The COVID-19 pandemic: major risks to healthcare and other workers on the front line. (2020): 281-282.

15-Fan-Yun Lan, Chih-Fu Wei, Yu-Tien Hsu, David C Chiristiani, Stefanos N Kales. Workrelated COVID-19 transmission. DOI: http://doi.org/10.1101/2020.04.08.2005829 7

16-Barbieri T, Basso G, Scicchitano S. Italian workers at risk during the Covid-19 epidemic. Available at SSRN 3572065. 2020 Apr 9.

17-Dy LF, Rabajante JF. A COVID-19 Infection Risk Model for Frontline Health Care Workers. medRxiv. 2020 Jan 1.

18-McMichael TM, Currie DW, Clark S, Pogosjans S, Kay M, Schwartz NG, Lewis J, Baer A, Kawakami V, Lukoff MD, Ferro J. Epidemiology of covid-19 in a long-term care facility in King County, Washington. New England Journal of Medicine. 2020 Mar 27.

19.Jahanpour Kianous Corona virus news:available at :Behdasht.gov.ir

20-Heinzerling A, Stuckey PM, Scheuer T, Xu K, Perkins KM, Resseger H, Magill S, Verani JR, Jain S, Acosta M, Epson E. Transmission of COVID-19 to health care personnel during exposures to a hospitalized patient-Solano County, California, February 2020. 